\title{
Modern Technology Trends Bring the Chance of Identity Originality Dikir Barat in Kelantan
}

\author{
Azlina Musa
}

\begin{abstract}
This paper discusses the threat of modern technology that has led to badly identity originality of the popular dikir barat tradition performances in Kelantan. The development of modern technology through the internet is very accessible at your fingertips. In addition to television, radio and dvd help to affect give the originality dikir barat. The emergence of modern dikir barat singer with a lack of basic knowledge has little to do with the traditional dikir barat style and structure. What changes are being made due to the saturation and anxiety of young thinkers about the long existence of the dikir barat tradition in Kelantan. Modern dikir barat are given new breaths is a desire to bury the native dikir barat that is considered outdated and outdated. The modernization or adaptation of dikir barat tradition to a new of modern dikir barat thought due to the application of foreign influences and the appearance of western elements is absorbed in western thought today. The advent of modern technology has also led to the gradual disappearance of the originality dikir barat style show that wants to channel information to the public. This discussion is also more a study of the change in the dikir west of tradition with society in the process of technological development today. Confusion exits among the younger generation, a new generation that is hard to identify with the originality dikir barat in Kelantan. Therefore, revitalizing the authenticity of the dikir barat tradition must be done so that modernity and technology are not threatened, lost and lost. Re-documenting this study could add further sources of refence to other researchers in the future.
\end{abstract}

Keywords : dikir barat, technology, impact, modernity

\section{INTRODUCTION}

Kelantan has always been popular with the dikir barat as a medium of entertainment to the community. As technology advances today it is changing the identity of the existing dikir barat. It also gradually lost structure and function shows due to the native Malays of Kelantan to form shows due to the more contemporary and modern. The change that young minds are trying to make is to meet the tastes of the new generation today.

The application of new elements to modern western performances by thinkers that are so widespread today has led to a compilation of the true identity of the origin of dikir barat performance in Kelantan. In this regard, the original dikir barat is the traditional musical legacy of the ancient ancestors, a treasure trove of the earliest entertainment in homeland music that should not be lost just as the modern

Revised Manuscript Received on March 17, 2020.

* Correspondence Author

Azlina Musa*, Pusat Pendidikan Asas dan Liberal, Universiti Malaysia Terengganu, 21030 Kuala Nerus, Terengganu, Malaysia

(C) The Authors. Published by Blue Eyes Intelligence Engineering and Sciences Publication (BEIESP). This is an open access article under the CC BY-NC-ND license (http://creativecommons.org/licenses/by-nc-nd/4.0/) technology advances. The westernization of the dikir barat in Kelantan by irresponsible parties should not be neglected.

According to Siti Zainol Ismail (1989) tradition is a unique system that has existed for hundreds of years and continues to this day. Humans must change as the technology progresses. However, the nature of the tradition in the dikir barat must be preserved in its authenticity. The compositions and adjustments made to the dikir barat tradition are to some extent influenced by western influence and modernity. Malay proverb mentions let off children do not die, which means indigenous customs that cannot be violated. Thus, the advances in modern technology should not completely alter the traditional dikir barat style structure of the existing hereditary heritage of the past.

Generally speaking, the original dikir barat is a legacy of past and traditional culture. The original dikir barat thought has become a popular practice in people's lives in the past. However, in today's modern society with the availability of facilities such as internet, you tube and electronic media such as radio, television, smartphones and various advances in communication technology has made the delivery of modern dikir barat music more accessible to the public. Besides the technology of bringing in dikir barat elements it is very fast to come in and influence the dikir barat of today.

\section{RESULT AND DISCUSSION}

Technology has brought the emergence of modern dikir barat thinkers where viewers can download their own modern dikir barat songs they love on the internet like you tube. Even the dikir barat is also broadcast on television and radio. Presentations include a number of modern dikir barat singers such as Wanie, Nur Akma, Kajol, Man Khan, Ain Manja, Aris Kapilla, Rosalinda, Fendi Kenali, Munirah, Jali, Eda Ezrin and many more.

The involvement of the modern dikir barat queer singer has been to some extent influenced by the changes in the development of the existing western queer world in Kelantan. Modern dikir barat singers song by female thinkers or male thinkers perform individual western performers (solo), duets (two people) or sing in groups that are easily viewed on the internet such as you tube.

Even the younger generation of thinkers also produce western-themed albums dikir barat such as jaguh album, a great $\mathrm{dk}$ album that can be purchased in the market that makes it easy for the audience to reach home. Traditional music, hindustan, pop and dangdut music are also included in dikir barat modern western music in Kelantan today. The modernization of the modern western music singer in music is something that can bury the authenticity of the western tradition of a monogamous tradition.

Published By:

Blue Eyes Intelligence Engineering

\& Sciences Publication

(C) Copyriaht: All riahts reserved.

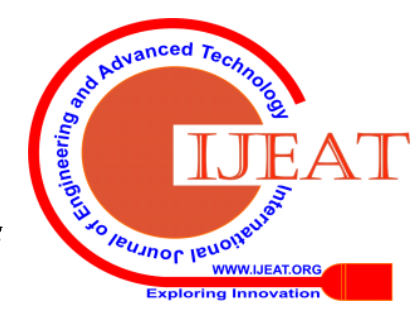


The new generation will lose interest and lose the true identity of the tradition dikir barat in Kelantan. Modern technology also affects the structure or shape of the west dikir barat. Additions to modern western songs that fit with the changing times have continued to be made by the young thinkers. As a result, the original dikir barat defending the original dikir barat shape or structure inherited by the ancient parents is eroded by technological modernity. This has resulted in the diversity of modern dikir barat song titles that have strayed far from the original form or structure of the original dikir barat songs presented to the audience.

Wan Abdul Kadir (1993) parents play an important role in preserving ancient traditions. A traditional dikir barat tradition that is a legacy of the past is one that brings value to the younger generation. Therefore, it should not be overlooked that the original form or structure of the original dikir barat is due to modernity. In addition to the rapid urbanization and modernization process of technological development it is difficult to maintain the authenticity of the west. Meanwhile, a new generation of young people increasingly exposed to the various changes brought about by technology has left them no longer interested in Kelantan's indigenous west, considered outdated, outdated and unfulfilled.

In addition, modernizing and incorporating new outdoor elements that are popular in dikir barat or contemporary dikir barat style will bring destruction to the authenticity of dikir barat Kelantan. While the modern dikir barat singer is hoping the public can respond to the reforms in the west. Today's modern thinkers who have brought western elements into the dikir barat have brought destruction to the authenticity of the dikir barat in Kelantan. Thus, such an act was not to preserve the tradition of the dikir barat but the nature of the dikir barat was modified according to the new taste.

In addition, the way of life in the technological age required a dikir barat supply that could meet the needs of the internet-accessible community. Technology has also brought changes to the production of modern dikir barat to meet the needs of the public. The production of modern dikir barat cuisine is for profit, to gain popularity and to meet the needs of the surrounding community.

Thus the various modern dikir barat styles produced by young thinkers are easily accessible on the internt by the public. Broadcasting of the dikir barat through you tube is a change in the form of the dikir barat. Besides that, the young people also want change for the dikir barat. The young audience, on the other hand, is very receptive to and influenced by the modern dikir barat choreography you watch on the you tube which is a novelty in entertainment and is a modernization trend that has undergone a change in the dikir barat.

Wan Abdul Kadir (1993) says that one trend in modern society is that young people are trying to create something new. The new creation is modern. This is contrary to what is happening in traditional society. Something new in dikir barat thought is contrary to tradition and is disliked by society especially by the elderly. Competition also exits between traditional dikir barat and modern dikir barat. Furthermore, the advancement of the internet such as you tube and electronic media such as radio in today's context prefers to play modern dikir barat songs as an advantage and to meet the demands of the market rather than broadcast traditional dikir barat songs because of the lack of response from the hearing community.

The competition in western entertainment has led to the loss of tradition in society and eventually burial. Technology is changing the role of the original dikir barat. Changes are also experienced in the modern or contemporary dikir barat. The original dikir barat mindset that has been adapted and adapted to technology has caused the authenticity of the dikir barat to disappear and disappear. This modification will eliminate the functionality and identity of the dikir barat in Kelantan. When the dikir barat concept is altered and adapted to the ideals of today's thinkers, composers, creators and technologies, the negative implication is that future generations of new viewers will not be able to recognize the true nature of western forms in Kelantan. Accordingly, the changes made by modern dikir barat chanters have not been made so that they can be retained in their original dikir barat

\section{A. The mastery of the foreign language in the modern dikir barat}

The efforr to change the authenticity of the dikir barat has been made by the dikir barat today to meet the demands of modern needs. Kelantan Malay dialect is compatible with the original dikir barat. However, Kelantan Malay dialect used in the song chants west is amended in modern dikir barat. So it is not surprising that modern dikir barat performances have used various languages such as moden or standard languages.

In recent times there have been attempts to change dikir barat performances by using modern languages and using English or Hindustan as one of the innovations of dikir barat performances to audiences. Standard language or a foreign language that is used by dikir barat is completely eliminate the use of Kelantan Malay dialect in shows due to the original.

Authenticity dikir barat are identified using the Kelantan Malay dialect shows due to the delivery. However, the act of changing the dikir barat Kelantan using standard language that aims to make the Malays from other states are able to understand it is a mistake to obscure the origin of dikir barat in the public eye.

In fact, there is also the act of changing the modern dikir barat by using English which aims to popularize the dikir barat to foreigners. The fact is that the work done by this renovation is not able to popularize the dikir barat tradition. The original position of the dikir barat is also lost in its essence and can bring destruction to the authenticity of the dikir barat.

In addition, a modern element cannot be adapted to new needs by the taste of its creator. The change of the dikir barat quadrant and the adaptation to the new requirements meant that it brought out the original elements in the context of the original quadrangular origin of the homeland. Original dikir barat are popular with Kelantan Malay dialect.

The use of modern or standard languages and English or the inclusion of other languages in the modern dikir barat dialect has changed or distorted the originality of the original dikir barat music. Just as the original dikir barat that have the essence of meaning and purpose in performing the Kelantan Malay dialect. When the originality of the performance of dikir barat performances is altered,

DOI: 10.35940/ijeat.B2957.049420

Journal Website: www.ijeat.org
Published By:

Blue Eyes Intelligence Engineering

\& Sciences Publication

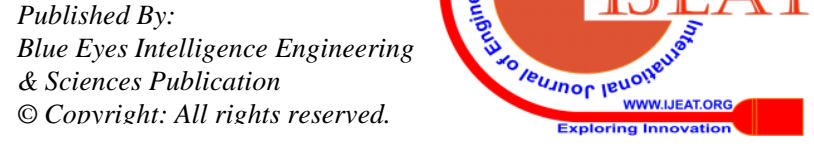


it is brought out and redefined in its presentation until the meaning and meaning of the presentation is to be presented to the audience. Thus, the performance of the dikir barat is not as memorable as it is today by the younger generation.

Thus, the original dikir barat cultural tradition chants that uses language Kelantan Malay dialect is to be maintained in its original state. This will bring pride to future generations. The loss of the identity of the native west is due to the development of the modern dikir barat. Think of the modern dikir barat that is so fast popular than the original dikir barat. Thus, efforts are made to preserve the identity of the original dikir barat in its original. The effort to maintain the original dikir barat is worth doing. If the original condition is to be repaired then the effort to repair it must maintain the original appearance of the original dikir barat so as not to be damaged by technology.

An easy-to-watch dikir barat performance on the you tube featuring modern song titles such as example abe love $\mathrm{u}$ all songs of singer Man Khan and Adik Wanie, tokseh carpet songs of singer Man Khan and Adik Wanie, singer Munirah's a pacat songs, cak kapok snake song by dinger Man Khan and Rosalinda and many more.

Therefore, the identity of the dikir barat origin must be maintained at all times to ensure the safety of the native west-end from being threatened and lost. In addition to maintaining the authenticity of the western chorus so that it is not altered or damaged by technological advances, the performance of the western chorus in the audience that performs the western choreography without maintaining its authenticity should be reproved. If the true identity of the west is changed, it will be at a disadvantage to future generations. Losing Kelantan Malay dialect in modern dikir barat these day are increasingly threatened and endangered. The use of standard languages or foreign languages brought into the modern dikir barat. The influence of the dikir barat or the modernity of technology has also had a negative impact on the dikir barat.

\section{B. Modification of the dikir barat Style Of Performance}

Clothing original dikir barat dressed in traditional clothing such as tshirts Malay examples songket, sampin, sloping manner for dikir barat man. Traditional dress is a reflection of the authenticity of western Kelantan. Technological advances have led to the unification of fashion identities in western performances. The Arab or Indian fashionable clothes are worn by contemporary thinkers. Modern dress by thinkers in today's dikir barat show like costume jeans, tshirts, skirts, hats. The western influence also has the effect of modifying the authenticity of the traditional fashion in the dikir barat performances in Kelantan.

\section{Performance Style}

The advent of modern technology has resulted in the modern dikir barat element being introduced into modern dikir barat music. Hindustan music that has been adapted to technological advances has been absorbed as an element of original dikir barat music. Therefore, traditional dikir barat must be maintained to determine the identity of the dikir barat as a popular cultural element in Kelantan. It also features a modernization of the lyrics of dikir barat songs that contain elements of satire, pornography, metaphor and politics in modern dikir barat songs. The traditional dikir barat mindset is a meaningful presentation embodied by the element of humor and the specific message conveyed in the lyrics of the song has the benefit it wants to convey to the audience.

\section{The Western Style of the Style of the Performances is Dikir Barat}

Dikir barat thought is a popular folk song in Kelantan. Dikir barat thought is a singing performance accompanied by traditional instruments such as gong, kesi, drums. Singing dikir barat art is a form of words that rhyme or rhyming phrases that amorphous and song in Kelantan Malay dialect in their delivery area.

Therefore, some of the most famous songs in the dikir barat tradition are like the moon song. In old days, dikir barat tradition was traditionally performed by western clubs to make it accessible to the public. The dikir barat tradition is to have a champion, a nobleman and a group of followers. The champion of dikir barat tradition has played an important role in the performance of the dikir barat. Meanwhile, the nonsense is always teasing the opposing team or answering the opponent's ridicule. The followers also sang onlu part of the poem song by chan chanters and clowns, and chanted choruses while clapping for drums and gongs, which were the background music of dikir barat.

Before the Malays recognize radio and television then dikir barat is a public entertainment activities in his spare time, especially after the harvesting season or even in the evening or night. The dikir barat mindset that was once traditional is presented in a relaxed atmosphere that can be seen in the village. The advances in modern technology have made the dikir barat easy to watch on you tube and dvd player at home. Even the audience can hear the dikir barat on the radio like the fm thriller that delivers a modern dikir barat that is well received by today's generation.

The style of modern dikir barat style performances is to bring in western elements. Accordingly, something brought in from outside Kelantan in the presentation of the modern dikir barat is coming from the west. The dikir barat elements in the modern dikir barat chorus is the dance by the female thinker in the show. Originally the dikir barat did not contain dance. However, in recent times the form of modern dikir barat dance performances has involved hands-on and dance moves.

The dikir barat element in the modern dikir barat chorus is the dance by the female thinker in the show. However, in recent times the form of modern dikir barat dance moves. In addition, the dikir barat beat songs that have been played in the past are also slightly different from the present. In the past dikir barat songs were at their own pace. But today in dikir barat songs often incorporate foreign elements such as Hindustan beats. This is for the taste of the audience.

E. The inclusion of foreign culture and the visual communication of western music

Technological advances bring in western or modern music that is absorbed in western music.

The inclusion of external influences as a foreign element in western music is either accidental or accidental in western music. The inclusion of Arabic music, Hindustan music, dangdut music, kpop music has also been absorbed as an element of western music that has been absorbed in today's dikir barat performances.

Published By:

Blue Eyes Intelligence Engineering

DOI: 10.35940/ijeat.B2957.049420

Journal Website: www.ijeat.org

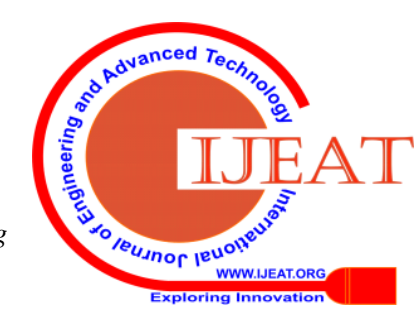


The inclusion of dikir barat choral music into original western choral music is becoming more and more practiced by modern dikir barat choreographers by bringing in rap music, ballads, rock has changed the identity of the original dikir barat chorus. Hindustan's use of rap music elements as a modification of dikir barat choral music has transformed the true dikir barat chorus.

In addition, the dikir barat element that is brought into the music of modern dikir barat music is the transmission of dikir barat ideology and values. Little by little, dikir barat modernity can influence society and its negative effects are also widespread. Therefore, dikir barat tradition must be maintained to define our culture as a symbol of its own culture.

Ismail Hamid (1991) is a traditional Malay music reflects the culture of the Malay community in the past. However, the development of pop music in dikir barat music today is not only a showcase of entertainment but an elements. But traditional Malay music is still perfect since describing something of the past.

In addition, as modern technology evolves rapidly, the original dikir barat position is also weakening. This is because, the native west is getting great competition from modern technology through the modern dikir barat. This is also due to the fact that the response from the public to the the native dikir barat is decreasing as it has to deal with the dikir barat. In addition, today's young people who are exposed to technological advances are increasingly less interested in native dikir barat. Even the younger generation today is also limited in time to watch the original dikir barat performances. So the younger generation opted for an alternative to the modern dikir barat that is easy to watch in you tube.

In addition, the competition of the native dikir barat and the entertainment of the modern dikir barat is more popular is the fact that the native dikir barat is less favored by the younger generation today. The spread and development of the native dikir barat have received little public support. This situation has also led to the development of modernity which has brought destruction to the native dikir barat. Modern technology has resulted in native dikir barat in Kelantan not being able to maintain their popularity as they have to compete with modern dikir barat with the ability to attract viewers to watch the internet.

In addition, the modern dikir barat singer who is actively developing and spreading the songs of the dikir barat in Kelantan is due to the support provided by the public. Signs of public support have also enabled modern westerners to move and flourish in spreading dikir barat expansions. This has an impact on the native dikir barat in the life of modern society which is considered outdated and outdated and cannot thrive because the public's interest in watching the native dikir barat is never the same. Today's young generation is also not interested in watching dikir barat tradition. The younger generation is also more inclined towards the modern dikir barat to meet their tastes.

\section{METHODOLOGY}

The methodology includes observations, interviews and is analyzed systematically as a complement to the findings.

\section{CONCLUSION}

A conclusion section is not required. Although a conclusion may review the main points of the paper, do not replicate the abstract as the conclusion. A conclusion might elaborate on the importance of the work or suggest applications and extensions.

Fundamentally this is also the existence of technology that has allowed the entry of dikir barat elements into the modern dikir barat. Technological advances have caused dikir barat elements to rapidly infiltrate dikir barat music. The result is that the authenticity of the dikir barat will be lost and lost by modernity and technology. But dikir barat tradition should be nurtured and preserved to the younger generation so that it can be enjoyed and valued. The dikir barat thought of tradition can inspire the younger generation to recognize the identity of the dikir barat. This is because the western trend of tradition should be maintained because it has a very important artistic value.

\section{REFERENCES}

1. Hasrul Hashim, Mohd Azul Mohammad Salleh \& Emma Mohamad. 2015. Analisis penggunaan kesan khas visual digital (DVFX) terhadap genre dan narrotologi filem pendek. Jurnal Komunikasi.

2. Ismail Hamid. 1991. Masyarakat dan budaya Melayu. Kuala Lumpur: Dewan Bahasa dan Pustaka.

3. Muhammad Nur Akmal Rosli \& Rohaidah Kamaruddin. 2018. Perbezaan budaya dalam terjemahan lagu-lagu P Ramlee. International Journal of the World and Civilisation.

4. Norshafawati Saari, Asiah Sarji \& Fauziah Kartini Hassan Basri. Muzik dan pembangunan sosial: paparan dasar industri hiburan dalam akhbar-akhbar di Malaysia. Jurnal Komunikasi.

5. Nurfarhana Shahira Rosly, Normaliza Abd Rahim \& Hazlina Abdul Halim. 2016. Interaksi antara ujaran kanak-kanak menerusi elemen pendigitalan dalam penceritaan. Journal of Language Studies.

6. Siti Zainol Ismail. 1989. Percikkan Seni. Kuala Lumpur: Dewan Bahasa dan Pustaka.

7. Wan Abdul Kadir. 1993. Transmisi budaya popular. Kota Bharu dan Petaling Jaya: Masfami Enterprise.

\section{AUTHORS PROFILE}

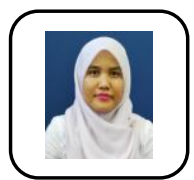

Azlina Musa, Studies Pusat Pendidikan Asas dan Liberal, Universiti Malaysia Terengganu.

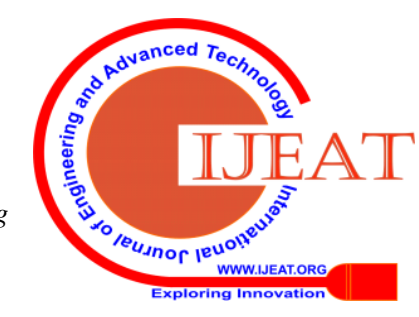

